\title{
Perbandingan Sekresi IL-10 di Jaringan Sekitar Luka Insisi Dengan dan Tanpa Infiltrasi Levobupivakain : Studi Imunohistokimia pada Tikus Wistar
}

Winarto*, Uripno Budiono*

*Bagian Anestesiologi dan Terapi Intensif FK Undip/ RSUP Dr. Kariadi, Semarang

\begin{abstract}
Background: The acute pain occurs after wound could depress the immune function that leads to the inhibition of the wound healing processes. Local anesthetic which has a long duration effect such as levobupivacain could be used to relief the pain so that protect the depression of immune function. Activation of macrophage can promote the $T$ cell to produce IL-10.
\end{abstract}

Objective: To compare the IL-10 secretion between levobupivacain tread and non levobupivacain on the tissue surround the wound.

Methods: A laboratoric experimental study designed with randomized post test only control group method. Thirty five female rats were randomly devided into three groups. Control group (K), Non-Levobupivacain infiltration group (P1) and Levobupivacain infiltration group (P2). No incision and no infiltration in $K$ group. Two cm of skin incision was performed to $P 1$ and $P 2$. After the incision, levobupivacain infiltration were given every 8 hours for 24 hours to the P2 group. No levobupivacain was given to the first group. On day $1^{\text {st }}, 2^{\text {nd }}, 3^{\text {th }}$ the rats were sacrified and the tissue surround the wound were taken for immunohistochemistry staining. The IL-10 secretion were analyzed for histologic scoring. Kruskal Wallis Test, Mann-Whitney Test were used for statistic analysis.

Result: It was demonstrated in this study that the histologic score of IL-10 of the levobupivacain treated group was significanly higher than non levobupivacain group in $2^{\text {nd }}$ day (mean $5.36 \pm 1.25$ vs $3.00 \pm 2.11$ respectively, $p=0,023 ; p<0,05$ ).

Conclusion: The IL-10 secretion was significantly higher in levobupivacain treated group than non levobupivacain group on the tissue surround the wound

Keyword: IL-10 secretion, levobupivacain infiltration, after incision pain

\begin{abstract}
ABSTRAK
Latar belakang : Nyeri menyebabkan peningkatan hormon glukokortikoid yang memperlama penyembuhan luka. Transmisi nyeri dapat dihambat dengan obat anestesi lokal levobupivakain. Terapi ini akan mengurangi supresi imunitas seluler sehingga fungsi makrofag dalam membantu aktifasi sel T tidak terhambat. Aktifasi sel T ini diduga akan meningkatkan sekresi IL-10.

Tujuan : Membandingkan sekresi IL-10 di jaringan sekitar luka dengan dan tanpa infiltrasi levobupivakain.

Metode: Eksperimental laboratorik dengan desain Randomized Post test only control group design, pada tiga puluh lima ekor tikus Wistar. Kelompok penelitian dibagi menjadi tiga kelompok secara acak, Kelompok Kontrol (K) 5 ekor, Perlakuan 1 (P1) dan Perlakuan 2 (P2) masing-masing lima belas ekor. Kelompok Kontrol, tikus tanpa insisi dan tanpa infiltrasi. Kelompok P1, tikus yang dilakukan insisi $2 \mathrm{~cm}$, tanpa diberikan infiltrasi levobupivakain. Kelompok P2, tikus yang dilakukan insisi $2 \mathrm{~cm}$, diberikan infiltrasi
\end{abstract}


levobupivakain tiap 8 jam selama 24 jam. Ekspresi IL-10 di sekitar luka insisi dinilai dengan skor histologi dari preparat dengan menggunakan pengecatan imunohistokimia, yang diambil dari biopsi jaringan pada hari ke 1, 2, dan 3. Metode perhitungan statistik menggunakan Kruskal Wallis Test dilanjutkan Mann Whitney Test.

Hasil: Hasil penelitian menunjukkan pada jaringan insisi rerata skor histologi IL-10 pada kelompok levobupivakain lebih tinggi $(5.36 \pm 1.25)$ dibanding kelompok tanpa levobupivakain $(3.00 \pm 2.11)$ pada hari ke dua. Perhitungan statistik antara kedua kelompok tanpa levobupivakain dan dengan kelompok levobupivakain berbeda bermakna $(p=0,023 ; p<0,05)$.

Kesimpulan: Sekresi IL-10 di jaringan sekitar luka dengan infiltrasi levobupivakain lebih tinggi dibanding tanpa levobupivakain

Kata Kunci: Sekresi IL-10, infiltrasi levobupivakain, nyeri pasca insisi.

\section{PENDAHULUAN}

Penyembuhan luka merupakan proses kompleks dan dinamis dari perbaikan struktur sel dan jaringan. Penyembuhan luka melibatkan berbagai proses dengan urutan : hemostasis, inflamasi akut, regenerasi sel parenkim, migrasi dan proliferasi sel parenkim, sintesis protein ECM, remodeling jaringan ikat dan komponen parenkim, kolagenasi dan akuisisi kekuatan luka. ${ }^{1,2}$ Pembagian secara garis besar meliputi fase inflamasi, proliferasi dan remodeling. ${ }^{3}$

Terdapat faktor sistemik dan lokal yang mempengaruhi penyembuhan luka. Salah satu faktor yang berperan adalah hormon glukokortikoid. Hormon ini mempunyai efek antiinflamasi, supresi netrofil, menghambat pembentukan fibroblast dan mengganggu sintesis kolagen. ${ }^{1}$ Elenkov dkk melaporkan bahwa glukokortikoid, katekolamin dan histamin akan menyebabkan supresi imunitas seluler dan respon imun humoral. ${ }^{4}$

Terjadinya proses penyembuhan luka tidak terlepas dari peran sitokin dan faktor pertumbuhan yaitu : PDGF, FGF, TGF- $\beta$, VEGF, Angiopoetin, IL-1, IL-6, IL 10 , TNF- $\alpha$, IFN- $\gamma$, makrofag yang diproduksi oleh limfosit dan lekosit pada tahap sintesis kolagen. ${ }^{1,2}$
IL-10 adalah salah satu sitokin anti inflamasi, berfungsi menghambat produksi beberapa jenis sitokin lain (TNF, IL-1, chemokine, dan IL-12 ), dan menghambat fungsi makrofag dalam membantu aktifasi sel T. Dampak akhir dari aktifasi IL-10 adalah hambatan reaksi inflamasi non spesifik maupun spesifik yang diperantarai oleh sel $\mathrm{T}^{5}$

Sato Y dkk, mengemukakan bahwa kadar IL-10 mencapai puncak 3 jam setelah insisi kulit tikus, lalu menurun normal sampai 24 jam, dan meningkat lagi serta mencapai puncak kedua pada 72 jam. ${ }^{6}$

Pembedahan menimbulkan respon stres berupa peningkatan sekresi hormon katabolik yaitu glukokortikoid, hipermetabolisme, aktivasi sistem otonom, peningkatan kerja jantung, rasa nyeri, gangguan terhadap paru, saluran cerna, gangguan sistem koagulasi, fibrinolitik dan imunosupresi. ${ }^{7}$

Pedersen mengurangi respon stres pembedahan dengan teknik pembedahan non invasif, penggunaan analgetik opioid dan blok saraf. Cara ini mampu menurunkan katabolisme protein, gangguan paru, mengurangi pelepasan katekolamin, kortisol dan glukosa. ${ }^{7}$ Bardram melaporkan teknik laparoskopi, anestesi ekstradural, nutrisi dini, mobilisasi dini, dan analgetik adekuat 
terbukti mampu mengurangi respon stres. 5

Infiltrasi bupivakain $0,25 \%$ dosis tunggal dapat mengurangi nyeri selama 24 jam pasca operasi. ${ }^{8}$ Penggunaan konsentrasi $0,25 \%$ lebih efektif dibandingkan $0,5 \%$, namun berbeda tidak bermakna dengan 0,125\%. ${ }^{8,9} \quad$ Penggunaan infiltrasi bupivakain pada dosis berulang dengan menyisipkan kateter subkutan pada ujung luka terbukti efektif mengurangi nyeri, tanpa komplikasi infeksi dan inflamasi lokal. ${ }^{9,10}$ Infiltrasi levobupivakain dapat mengurangi intensitas nyeri, menurunkan respon stres $^{6}$ sehingga menurunkan sekresi hormon glukokortikoid. ${ }^{1,2}$

Berdasar teori tersebut, penurunan hormon glukokortikoid ini akan mengurangi supresi imunitas seluler sehingga fungsi makrofag dalam membantu aktifasi sel T tidak terhambat. Aktifasi sel $\mathrm{T}$ ini diduga akan meningkatkan sekresi IL-10.

Semakin berkembangnya ilmu biologi molekuler memungkinkan identifikasi sekresi IL-10 pada jaringan, sehingga penelitian guna mengetahui perbedaan sekresi IL-10 pada penanggulangan nyeri insisi dengan infiltrasi obat anestesi local dan tanpa infiltrasi levobupivakain perlu dilaksanakan.

\section{METODE PENELITIAN}

Penelitian ini merupakan penelitian eksperimental laboratorik dengan desain Randomized Post test only control group design. Kelompok penelitian dibagi menjadi Kelompok Kontrol (K), Perlakuan 1 (P1) dan Perlakuan 2 (P2) dengan penjelasan sebagai berikut:

$\mathrm{K}$ : Kelompok Kontrol, tikus Wistar yang tidak dilakukan insisi dan tidak diinfiltrasi.

P1: Kelompok perlakuan 1, tikus Wistar yang dilakukan insisi sepanjang 2 $\mathrm{cm}$, disuntik ulang tanpa obat $2 \mathrm{x}$ setiap 8 jam berikutnya.

P2 : Kelompok Perlakuan 2, tikus Wistar yang dilakukan insisi sepanjang 2 $\mathrm{cm}$, diberikan infiltrasi levobupivakain di sekitar luka dan diinfiltrasi ulang $2 x$ setiap 8 jam berikutnya

Hewan coba adalah tikus jenis Wistar yang diperoleh dari Fakultas Peternakan UGM, Yogyakarta.

Kriteria Inklusi:

- Tikus Wistar

- Keturunan murni

- Umur dua sampai setengah bulan

- Berat badan 250-300 gram.

- Tidak ada abnormalitas anatomis yang tampak

Kriteria ekslusi:

- Sakit (gerakan tidak aktif) selama masa adaptasi 7 hari

- Mati selama perlakuan berlangsung (drop out).

Besar sampel :

menurut rumus WHO tiap kelompok minimal 5 ekor. Pada penelitian ini jumlah sampel yang digunakan 35 ekor yang dibagi menjadi 3 kelompok.

Randomisasi :

35 tikus dikelompokkan secara random menjadi tiga kelompok yaitu:

- Kelompok kontrol (K): 5 ekor

- Kelompok perlakuan 1 (P1): 15 ekor

- Kelompok perlakuan 2(P2): 15 ekor

Penelitian dan pengumpulan data dilakukan selama 6 bulan. Perlakuan dan proses pengambilan jaringan pada tikus dilakukan di Unit Pemeliharaan Hewan Coba Bagian Histologi Universitas Diponegoro Semarang. Fiksasi dan proses pewarnaan dilakukan di Laboratorium Patologi Anatomi Fakultas 
Kedokteran Universitas Sebelas Maret, Surakarta. Sementara interpretasi hasil dilakukan di Laboratorium Biomedik Universitas Sebelas Maret, Surakarta.

Sejumlah 35 ekor tikus Wistar dilakukan adaptasi di laboratorium dengan dikandangkan secara individual dan diberi pakan standar secukupnya selama 7 hari. Tikus dibagi menjadi tiga kelompok yang dilakukan secara acak masing-masing terdiri dari 5 ekor tikus untuk Kelompok Kontrol (K), 15 ekor tikus untuk Kelompok Perlakuan 1 (P1) dan 15 ekor tikus untuk Kelompok Perlakuan 2 (P2).

Setelah adaptasi selama 7 hari, tikus-tikus dari kelompok perlakuan maupun kontrol dibius dengan menggunakan ether. Sesudah terbius, bulu disekitar punggung dicukur bersih dan disinfeksi menggunakan betadine. Selanjutnya dibuat irisan sepanjang $2 \mathrm{~cm}$ dan kedalaman sampai subkutan. Luka irisan dibersihkan dan diolesi larutan betadine, kemudian luka ditutup dengan 5 jahitan tunggal sederhana menggunakan benang side.

Infiltrasi dilakukan pada kelompok P2 berupa larutan bupivakain 0,25\% memakai spuit tuberculin disekitar luka irisan. Sedangkan pada kelompok P1 suntikan dengan spuit tuberculin tanpa obat. Selanjutnya jahitan dibersihkan dan dioles dengan betadine dan dirawat. Pasca bedah diberikan penicillin oil 15 mg, intra muskular. Pengulangan penyuntikan baik dengan atau tanpa levobupivakain dilakukan sebanyak dua kali dengan tenggang waktu 8 jam.

Pada hari ke 1,2 dan 3 pasca perlakuan, pada ketiga kelompok masing-masing diambil 5 ekor. Dilakukan pembiusan dengan menggunakan ether. Setelah tikus terbius kemudian dibuat eksisi-biopsi.
Jaringan biopsi diproses menjadi preparat histologik setelah dibuat dengan blok parafin. Dilakukan pengecatan imunohistokimia dengan antibodi monoclonal anti IL-10. Interpretasi hasil dilakukan di Laboratorium Biomedik Fakultas Kedokteran UNS Surakarta.

Pada hari ke 1,2,3 pasca perlakuan, pada kedua kelompok masing-masing diambil 5 ekor. Dilakukan pembiusan dengan menggunakan ether. Setelah tikus terbius kemudian pada jaringan bekas irisan diusap dengan alkohol $70 \%$ lalu dibuat eksisi-biopsi kira-kira $0,5 \mathrm{~cm}$ persegi melintasi garis irisan pada bagian tengah dan tepi. Jaringan biopsi diproses menjadi preparat histologik setelah dibuat dengan blok paraffin.

Prosedur pembuatan preparat histopatologi

a. Fiksasi

Jaringan eksisi biopsy dimasukkan kedalam larutan formalin buffer ( larutan formalin $10 \%$ dalam buffer Natrium asetat sampai mencapai $\mathrm{pH}$ 7,0 ). Waktu fiksasi jaringan 18-24 jam. Setelah fiksasi selesai, jaringan dimasukkan dalam larutan aquadest selama 1 jam untuk proses penghilangan larutan fiksasi.

b. Dehidrasi

Potongan jaringan dimasukkan dalam alcohol konsentrasi bertingkat. Jaringan kemudian dimasukkan dalam larutan alcohol-xylol selama 1 jam dan kemudian larutan xylol murni selama $2 \times 2$ jam.

c. Impregnasi

Jaringan dimasukkan dalam paraffin cair selama $2 \times 2$ jam

d. Embedding

Jaringan ditanam dalam paraffin padat yang mempunyai titik lebur $56-58^{\circ} \mathrm{C}$, ditunggu sampai paraffin padat. Jaringan dalam paraffin dipotong setebal $4 \mu \mathrm{m}$ dengan mikrotom. 
Potongan jaringan ditempelkan pada kaca obyek yang sebelumnya telah diolesi polilisin sebagai perekat. Jaringan pada kaca obyek dipanaskan dalam incubator suhu $56-58^{\circ} \mathrm{C}$ sampai paraffin mencair.

Prosedur pembuatan preparat imunohistokimia merupakan metode pemeriksaan pewarnaan jaringan berdasar kerja imunoenzym untuk memeriksa adanya antigen atau mencari lokasi antigen dalam specimen.

Imunohistokimia dilaksanakan berdasarkan pada interaksi antigen antibodi yang terjadi antara marker IL-10 dengan antibodi primer. Deteksi yang digunakan adalah deteksi kromogenik berdasarkan warna yang timbul sebagai akibat reaksi enzimatis yang terjadi antara enzim HRP dengan substratnya. Sistem deteksi yang digunakan dalam penelitian ini adalah Novocasta.

Fiksasi sediaan dilaksanakan dengan tehnik presipitasi menggunakan etanol dan dengan pengikatan silang menggunakan paraformaldehide $2 \%$. Pretreatment sediaan sesudah deparafinisasi dan rehidrasi. Langkah ini dilaksanakan. Dengan inaktivasi enzim peroksidase endogenous dengan menggunakan $3 \% \mathrm{H}_{2} \mathrm{O}_{2}$ dalam methanol atau PBS selama 30 menit. Blocking dilakukan dengan menggunakan buffer blocking TNB selama 30 menit pada temperature kamar. Pemberian antibodi primer dilakukan pada suhu kamar selama 30 menit. Pencucian slide dilaksanakan dengan buffer $\mathrm{PBS} \mathrm{pH}=7,4$ selama $3 \times 5$ menit pada temperature kamar. Slide selanjutnya direaksikan dengan antibodi sekunder yang berlabel Biotin.

Deteksi dilaksanakan secara kromogenik berdasarkan pada intensitas warna yang timbul setelah slide direaksikan dengan SA-HRP dan DAB (diaminobenzidine) dan $\mathrm{H}_{2} \mathrm{O}_{2}$ sebagai substrat enzim peroksidase.

Pengamatan dilaksanakan dengan mikroskop cahaya dalam skala pembesaran 400x. Dipilih lapang pandang yang paling banyak area positifnya, selanjutnya dihitung (dilakukan cropping) jumlah area positif pada lima lapang pandang searah jarum jam. Dengan mikroskop OLYMPUS seri BX 41 yang dilengkapi dengan kamera digital DP-70 dan memakai software OLYSIA, intensitas warna dan area IL-10 dapat diketahui. Tingkat ekspresi ditentukan secara kuantitatif sebagai nilai rata-rata pengamatan. Masing masing sediaan diteliti sebanyak lima lapang pandang dan nilai dari setiap lapang pandang akan dihitung sebagai nilai skor histologi untuk memperoleh ekspresi IL10 secara kuantitas.

Penilaian skor histology IL-10 berdasar presentasi dan intensitas.

Jika Persentasi :

0 : tidak area positif

1: area positif $1-25 \%$

2:area positif $26-50 \%$

3: area positif $51-75 \%$

4: area positif $76-100 \%$

Intensitas :

0 : tidak terwarnai/negative

1: positif lemah.

2: positif sedang.

3: positif kuat.

Nilai ekspresi IL-10 ditentukan dengan rumus sebagai berikut :

Skor $=($ IK $x$ PK $)+($ IS $\times$ PS $)+$ $($ IL $x$ PL $)+($ IN $x$ PN $)$

$\mathrm{I}=$ Intensitas.

$\mathrm{P}=$ Persentase $\left(\right.$ Luas Area dalam $\mu \mathrm{m}^{2}$ )

$\mathrm{K}=$ kuat

$\mathrm{S}=$ sedang 
$\mathrm{L}=$ lemah

$\mathrm{N}=$ negative

( Leake, et al. 2000 )

Skor dari kelima lapang pandang kemudian dirata-rata untuk menentukan nilai ekspresi secara kuantitatif dari sediaan tersebut.

Data dikumpulkan dan diolah dengan menggunakan computer SPSS 13.0 for windows dan dinyatakan dalam rerata \pm simpang baku ( mean \pm SD ). Kemudian dilakukan uji beda skor histologi IL-10 antar kelompok dengan menggunakan uji Kruskal Wallis. Dengan batas derajat kemaknaan $\mathrm{p}<0,05$ dengan 95\% interval kepercayaan dan penyajian dalam bentuk table dan grafik.

\section{HASIL}

Telah dilakukan pengecatan imunohistokimia dengan menggunakan antibodi monoclonal mouse (MoAb) anti IL-10 terhadap 35 sediaan jaringan biopsi kulit tikus Wistar. Masing-masing kelompok diwakili 5 sediaan uji. Dengan mikroskop OLYMPUS seri BX 41 yang dilengkapi dengan kamera digital DP-70 dan memakai software OLYSIA, intensitas warna dan area IL-10 dapat diketahui sebagai nilai kuantitatif.

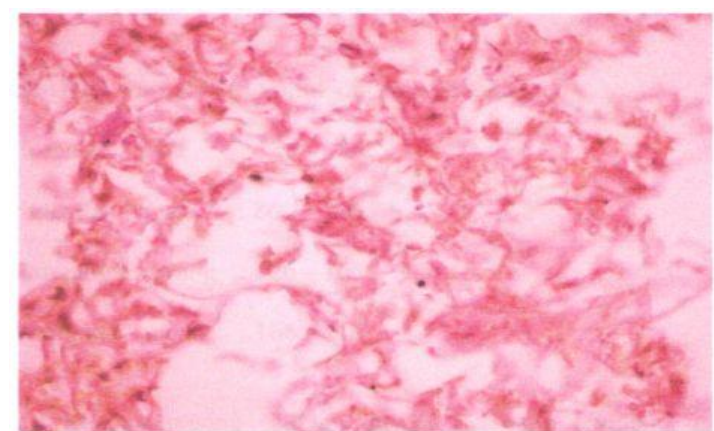

Gambar 2. Contoh hasil foto hari ketiga kelompok tanpa levobupivakain ( kode preparat 3P1.3D )

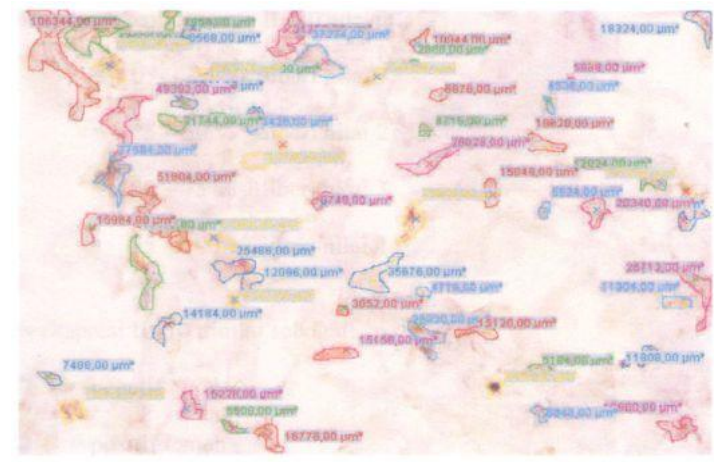

Gambar 3. Contoh hasil cropping dengan menggunakan software OLYSIA Preparat dengan kode 3P2.1B.

Nilai intensitas warna dikelompokkan sebagai berikut :

Intensitas kuat $\quad: 45-85$

Intensitas lemah $\quad: 86-125$

Intensitas sedang : :126-165

Intensitas negatif $\quad: 166-206$

Masing-masing sediaan dilihat 5 lapang pandang, dan nilai setiap lapang pandang akan dihitung sebagai nilai skor histologi guna menentukan nilai sekresi IL-10 secara semi kuantitatif.

Sistem perhitungan dengan penentuan skor histologi adalah sebagai berikut :

Jika presentasi luas area IL-10 adalah :

$0-25 \%$ diberi nilai 1

$25-50 \%$ diberi nilai 2

$50-75 \%$ diberi nilai 3

$75-100 \%$ diberi nilai 4

Intensitas eksperisi IL-10 adalah :

$0=$ negatif

$1=$ positif lemah

$2=$ positif sedang

$3=$ positif kuat

Nilai skor histologis tampilan IL-10 ditentukan dengan rumus sebagai berikut: Skor Histologis :

( IK x PK ) + ( IS x PS ) + ( IL x PL ) + ( IN x PN )

Dengan :

$\mathrm{P}=$ persentase.

$\mathrm{K}=$ intensitas positif kuat. 
$\mathrm{L}=$ intensitas positif lemah.

$\mathrm{I}=$ intensitas

$\mathrm{S}=$ intensitas positif sedang

$\mathrm{N}=$ intensitas negatif. (Leake, et al., 2000).

Skor histologis tampilan IL-10 dari kelima lapang pandang kemudian diambil rerata untuk menentukan ekspresi secara kuantitatif dari sediaan tersebut. Hasilnya adalah sebagai berikut :

Tabel 2. Hasil pengamatan rerata \pm SD (Median) skor histology IL-10

\begin{tabular}{|c|c|c|c|c|}
\hline No & $\begin{array}{l}\text { KODE } \\
\text { SAMPEL }\end{array}$ & HARI KE 1 & HARI KE 2 & HARI KE 3 \\
\hline 1. & Kontrol & $\begin{array}{c}6,04 \pm 0,52 \\
(6,20)\end{array}$ & $\begin{array}{c}6,04 \pm 0,52 \\
(6,20)\end{array}$ & $\begin{array}{c}6,04 \pm 0,52 \\
(6,20)\end{array}$ \\
\hline 2. & Tanpa Levo & $\begin{array}{c}6,40 \pm 0,68 \\
(6,20)\end{array}$ & $\begin{array}{c}3,00 \pm 2,11 \\
(1,60)\end{array}$ & $\begin{array}{c}4,63 \pm 1,88 \\
(5,50)\end{array}$ \\
\hline 3. & Dengan Levo & $\begin{array}{c}5,48 \pm 2,72 \\
(5,80)\end{array}$ & $\begin{array}{c}5,36 \pm 1,25 \\
(5,60)\end{array}$ & $\begin{array}{c}6,40 \pm 0,82 \\
(7,00)\end{array}$ \\
\hline
\end{tabular}

Keterangan : Satuan dalam skor histologi.

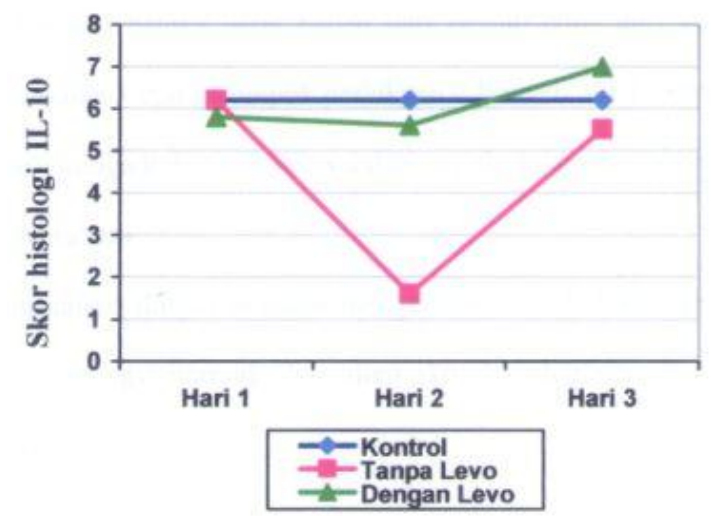

Gambar 4. Grafik rerata skor histologi IL-10

Uji homogenitas (uji beda) ditujukan untuk mengetahui apakah data parameter klinis atau laboratoris dari ketiga kelompok berasal dari populasi yang homogen.

Uji normalitas ditujukan untuk mengetahui apakah data parameter klinis atau laboratoris berdistribusi normal. Pengujian skor histology IL-10 dilakukan dengan tehnik Shapiro-Wilk.
Tabel 4. Uji normalitas data skor histologi.

\begin{tabular}{lcccc}
\hline & \multicolumn{4}{c}{ Uji statistik } \\
& HARI & Shapiro-Wilk & Df & Sig. \\
\hline Kelompok Kontrol & 1 & .894 & 5 & .376 \\
& 2 & .672 & 5 & .005 \\
Kelompok Tanpa Levo & 3 & .954 & 5 & .765 \\
& 1 & .894 & 5 & .376 \\
Kelompok Dengan Levo & 2 & .754 & 5 & .033 \\
& 3 & .788 & 5 & .065 \\
& 1 & .894 & 5 & .376 \\
& 2 & .870 & 5 & .268 \\
& 3 & .722 & 5 & .016 \\
\hline
\end{tabular}

Dari tabel 4 menunjukan kelompok control, kelompok tanpa levobupivakain varian datanya tidak normal.

Tabel 5. Hasil uji beda Kruskal Wallis Test skor histology IL-10 antara kelompok tanpa levobupivakain dan kelompok dengan levobupivakain

\begin{tabular}{cccc}
\hline & Hari 1 & Hari 2 & Hari 3 \\
\hline $\mathrm{X}^{2}$ & 0.513 & 7.552 & 3.432 \\
$d f$ & 2 & 2 & 2 \\
Nilai P & 0.774 & 0.023 & 0.180 \\
\hline
\end{tabular}

Dari tabel 5 diatas menunjukkan pada hari pertama $(p=0.774 ; p>0.05)$ dan pada hari ke tiga $(p=0.180 ; p>0.05)$ berbeda tidak bermakna. Sedangkan pada hari ke 2, skor histology IL-10 antara kelompok tanpa levobupivakain dan kelompok dengan levobupivakain berbeda bermakna $(p=0.023 ; p<0.05)$. Uji lebih lanjut dengan test Mann - Whitney $U$ juga menunjukkan berbeda bermakna (tabel 6).

Hal ini menunjukkan bahwa pada luka insisi hewan coba dengan infiltrasi levobupivakain sekresi IL-10 pada hari ke 2 secara bermakna lebih banyak di banding pada hewan coba tanpa infiltrasi anestesi local levobupivakain. 
Tabel 6. Hasil uji beda Mann - Whitney U Test skor histology IL-10 antara Kelompok tanpa levo dan kelompok dengan levo pada hari kedua

\begin{tabular}{cc}
\hline & HARI ke 2 \\
\hline Mann-Whitney $U$ & 2.000 \\
Wilcoxon $W$ & 17.000 \\
$\mathrm{Z}$ & -2.207 \\
Nilai P & .027 \\
\hline
\end{tabular}

\section{PEMBAHASAN}

Dalam penelitian ini dilakukan pada 35 ekor tikus betina GALUR Wistar dewasa yang dibuat insisi pada punggung, kemudian dilakukan infiltrasi anestesi lokal levobupivakain pada sekitar luka dan dilihat perbedaannya terhadap skor histologi IL-10 pada hari kesatu, kedua dan ketiga.

Untuk uji homogenitas kedua kelompok dengan variabel yang dapat diukur yaitu berat badan, hasil statistik menunjukkan berbeda tidak bermakna dengan $\mathrm{p}=0.733$ ; p>0.05 (tabel 3). Berarti kedua kelompok berasal dari populasi yang homogen, pada umumnya tikus berasal dari satu indukan dimana mempunyai karakteristik yang mirip.

Pengambilan biopsi jaringan pada luka dilakukan pada hari satu, dua dan tiga, karena IL-10 berperan pada fase inflamasi proses penyembuhan luka sehingga pada pemeriksaan imunohistokimia diharapkan terdapat IL10 dalam jumlah yang bermakna untuk dibandingkan antara yang diberi perlakuan dan tidak.

Menurut Constantinnides P, (1994) bahwa luka insisi akan menimbulkan nyeri. Nyeri akut bila tidak dikelola dengan tepat akan berakibat memperpanjang fase katabolic berupa peningkatan glucagon, kortikoid, dan resistensi insulin. Nyeri akan merangsang kelenjar pituari melepaskan adrenocorticotropin hormone (ACTH) yang selanjutnya akan mengaktifkan kelenjar adrenal sehingga melepas hormone steroid (kortisol). Hormon steroid yang tinggi akan meniombulkan disregulasi system imun berakibat terjadi penurunan ketahanan tubuh yang dapat menurunkan sekresi IL-10, sehingga menghambat penyembuhan luka.

Dengan menghambat jalur nyeri menggunakan infiltrasi levobupivakain di sekitar luka insisi, diharapkan sistem imun tidak terganggu sehingga skor histologi IL-10 tidak menurun dan penyembuhan luka dapat lebih baik. Seperti penelitian yang dilakukan oleh Mulyata S, (2002) stress pada hewan coba menyebabkan hambatan kesembuhan luka pasca episiotomi. Hewan coba tidak stres, kesembuhan lukanya lebih cepat. Vintar N, (2002) melaporkan penggunaan lokal anestesi bupivakain lewat kateter dalam luka akan efektif mengurangi nyeri setelah operasi hernia inguinalis dan penyembuhan luka lebih baik.

Penelitian ini, bertujuan membuktikan perbedaan sekresi IL-10 dengan dan tanpa infiltrasi levobupivakain pada nyeri pasca insisi disekitar luka. Hasil penelitian menunjukkan bahwa pada hari kedua rerata dari kelompok dengan levobuvipakain lebih tinggi $(5.36 \pm 1.25)$ dari kelompok levobupivakain (3.00 \pm 2.11$)$.

Analisis statistik skor histologi IL-10 pada jaringan sekitar luka dipengaruhi oleh pemberian infiltrasi anestesi loka levobupivakain, perbedaannya bermakna $\mathrm{p}=0.023 \quad ; \mathrm{p}<0.05 \quad$ (tabel 6), artinya terdapat perbedaan skor histologi IL-10 dengan infiltrasi levobupivakain dibanding tanpa infiltrasi levobupivakain dibanding tanpa infiltrasi levobupivakain hari kedua pada nyeri pasca insisi sekitar luka. Hal ini menunjukkan bahwa pada luka insisi hewan coba yang diinfiltrasi 
anestesi lokal levobupivakain jumlah IL10 secara bermakna lebih tinggi dibanding pada hewan coba tanpa infiltrasi anestesi lokal levobupivakain pada hari kedua.

Sato Y (1999) mengemukakan bahwa kadar IL-10 pada luka akut akan meningkat 3 jam setelah insisi kemudian turun normal dan meningkat lagi pada 72 jam setelah insisi. Pola kurva yang terbentuk (pola huruf V) mirip dengan pola pada penelitian ini tanpa infiltrasi levobupivakain. Sedangkan pada kelompok dengan infiltrasi levobupivakain pola membentuk garis lurus mendatar, berarti sekresi IL-10 tetap dipertahankan untuk menekan agar fase inflamasi tidak memanjang.

IL-10 terutama diproduksi oleh Th2 akibat rangsangan aktifasi makrofag. Sedangkan makrofag muncul pertama 4896 jam setelah terjadi luka dan mencapai puncak pada hari ke 3. Adanya ekspresi IL-10 pada hari pertama baik kelompok control, tanpa levobupivakain dan kelompok dengan levobnupivakain karena IL-10 juga diproduksi oleh sel-sel B dan keratinosit serta neutrofil meskipun dalam jumlah yang sedikit.

Hollman (2000) mengemukakan bahwa makrofag tetap di dalam luka sampai proses penyembuhan berjalan sempurna. Nyeri yang tak dikelola dengan baik menyebabkan kortisol tetap tinggi, hal ini mengakibatkan depresi pada Th2 sehingga produksi IL-10 akan menurun. Akibatnya tidak ada yang menahan makrofag dalam memproduksi sitokin pro-inflamasi sehingga fase inflamasi relatif menjadi lebih panjang.

Dengan infiltrasi levobupivakain menyebabkan blok/terputusnya transmisi nyeri sehingga respon akibat nyeri tidak terjadi, seperti tampak pada gambar 2, sekresi IL-10 mendekati harga kontrol.

Setelah makrofag muncul (48 jam setelah insisi) mengakibatkan Th2 memproduksi IL-10, pada kelompok dengan levobupivakain mencapai harga sesuai kontrol pada hari kedua lebih, sedangkan pada kelompok tanpa levobupivakain pada hari ketiga belum mencapai harga sesuai kontrol (gambar 2). Dengan kata lain (onset) hambatan terhadap makrofag terjadi lebih cepat pada kelompok dengan levobupivakain dibandingkan tanpa levobupivakain. Percepata hambatan ini akan mempersingkat fase inflamasi dan diharapkan proses penyembuhan menjadi lebih singkat.

\section{SIMPULAN}

Sekresi IL-10 dijaringan sekitar luka dengan infiltrasi levobupivakain lebih tinggi dibandingkan tanpa infiltrasi levobupivakain pada nyeri pasca insisi.

Berdasarkan hasil penelitian tersebut dapat disarankan sebagai berikut:

Pada luka insisi operasi dilakukan infiltrasi anestesi local levobupivakain pada sekitar luka karena sekresi IL-10 akan tetap dipertahankan dibandingkan tanpa levobupivakain pada jaringan sekitar luka sehingga penyembuhan luka menjadi lebih baik.DIlakukan penelitian dengan jangka waktu yang lebih lama untuk mengetahui lebih banyak mekanisme biomolekuler pengaruh infiltrasi levobupivakain terhadap penyembuhan luka

\section{DAFTAR PUSTAKA}

1. Cotran RS, Kumar V, Collins T. Pathology basic of disease. $6^{\text {th }}$ ed.Philadelphia:WB Saunders Co, 1999: 201-21.

2. Constantinnides P. General pathobiology. $1^{\text {st }}$ ed. Norwalk Connecticut : Appleton and Lange, 1994 : 173-86.

3. Mast AB. Normal wound healing. In : Achauer BM, Eriksson E, eds. Plastic 
Surgery, Indications, Operations and Outcomes, Mosby : Mosby Inc, 2000 : 37-53

4. Elenkov IJ, Webster E, Torpy Dj, et al. Stress, corticotrophin-releasing hormone, glococorticoids, and the immune inflammatory response : acute and cronic effects. Annals of the New York academy of sciences 1999; $876: 1-13$. Available from : http://annalsnyas.org/cgi/876/1/1

5. Bardram L, Funch - Jensen $P$, Kehlet $H$. Recovery after laparoscopic colonic surgery with epidural analgesia and early oral nutrition and mobilization. Lancet $1995 ; 345$ : 763-4

6. Sato Y, Ohshima T, Kondo T. Regulatory of endogenous interleukin-10 in cutaneus inflammatory response ofmurine wound healing. Biochem Biophys Res Commun. 1999 Nov;265 (1):194-9

7. Pedersen D. Accelerated surgical stay programe. Annals of Surgery $1994 ; 219$ : 374-81.

8. Christie Jm, Chen GW. Secondary hyperalgesia is not affected by wound infiltration with bupivakain. Can $\mathrm{J}$ of An 1993 ; 40 : 1034-37

9. Petterson N, Berggren P, Larsson M, et al. Pain relief by wound infiltration with bupivacaine or high dose ropivacaine after inguinal hernia repair. Reg Anesth Pain Med $1999 ; 24$ : 569-75.

10. Bultmann M, Streich R, RIsse A, et al. Postoperative analgesia in children after hernioplasty, wound infiltration with different concentrations of bupivacaine: a pilot study (German). Anaesthesist $1999 ; 48$ : 439-43.

11. Scheres H.M.E, Goei A.F.P.M, rousch M.J.m. Qualification of oestrogen receptors in breast cancer: radiochemical assay on cytosols and cryostat sections compared with semiquantitative immunocytochemical analysis. J Clin Pathol 1988; 41 : 623-6 